\title{
Development of Interactive Spruce Stands Map for Monitoring Ecosystem Recovery
}

\author{
Irina Volkova ${ }^{1 *}$, Natalia Zakharova ${ }^{2}$, George Nesterov ${ }^{3}$, \\ Sergey Kondrashev ${ }^{2}$, Ilia Aksenov ${ }^{4}$

\begin{abstract}
'Department of Social and Economic Geography, Institute of Geography RAS, Moscow, Russian Federation ${ }^{2}$ Department of Chemistry, Sechenov First Moscow State Medical University, Moscow, Russian Federation ${ }^{3}$ Department of Pharmacy, Sechenov First Moscow State Medical University, Moscow, Russian Federation ${ }^{4}$ Department of State Law and Customs Administration, Vladimir State University named after Alexander Grigoryevich and Nikolai Grigoryevich Stoletovs, Vladimir, Russian Federation
\end{abstract}

Received: 5 November 2020

Accepted: 25 December 2020

\begin{abstract}
The aim of the study is to develop interactive spruce stands map of two model landscapes of the Moscow region, Russia (Istrinsky and Luzgarinsky) considering the foci of insects' mass reproduction. The studies were carried out in 2016, in the Moscow region (Russia). For comparative analysis of spruce forests and stands for the Istrinsky and Luzgarinsky landscape, an interactive map based on Landsat satellite images has been developed, and cartographic data from 1991 to 2016 has been analyzed. The survey was carried out on a model area of 190 hectares in Kurilovo (Moscow region) at an altitude of $300 \mathrm{~m}$ using an unmanned aerial vehicle (UAV) Ptero-E. The processing of satellite images showed an unequal decrease in forest cover for the spruce forests and stands during 1991-2016, namely from $53 \%$ to $44 \%$ and from $73 \%$ to $70 \%$ in the Istrinsky and Luzgarinsky landscape, respectively. The data obtained with the UAV helped to determine the area affected by the bark beetle (Ips typographus), one of the most destructive pests of spruce trees, especially those that are over 70 years old: 3.2 out of 93.6 hectares of the total area of spruce forests. The short-term productivity and conditional inference forests decreased in area by $67 \%$ during 1991-2016, while long-term productivity - only by $28 \%$.
\end{abstract}

Keywords: spruce forests, monitoring, interactive map, UAV, forest cover

\section{Introduction}

Dynamism and irreversibility of the ongoing processes are the main characteristic properties of plant communities, including forest, that can lead to a complete replacement of the community or death.

*e-mail: ivolkova87@rambler.ru
Thus, the first processes are related to succession and the second to degradation. The time intervals of such changes are crucial. The process may continue for tens or hundreds of years due to succession, or occur almost instantly due to e.g. forest fires, causing the death of the forest-forming species [1]. Landslides, floods, and massive deforestation are other causes of sudden changes in the species composition and structure of forest communities due to natural disasters. Specifically, changes in forest communities are caused by external 
factors. Internal causes are mostly associated with the nature of the stand development and mass reproduction of insects. The mass reproduction of insects (xylophages and phyllophages) leads to large-scale but fragmentary damage to forest areas [2]. The insect outbreak manifests as spots, which look like areas of dry trees, or areas with fallen trunks. A characteristic feature of insects' mass reproduction is the cyclicity of forest damage, associated with climatic conditions of a region and developmental stages of insects. Moreover, insects' outbreaks are presented as periodic travelling waves occurring in different regions or even continents [3].

A bark beetle (Ips typographus Linnaeus) is the most dangerous pest for spruce (Picea abies Linnaeus) trees [4]. While the major habitat of the bark beetle is spruce, it may also attack cedar, larch and other conifers, yet the damage may be less than with the spruce. Dry periods, which seem to extend each year, favor the breeding of the typographer beetle. Specifically, in the summer of 2010, in the European part of Russia (Moscow region), abnormally high temperatures caused the drying of some spruce forests and the development of a food supply suitable for bark beetles of the genus typographer [5]. Thus, a great amount of dry wood contributes to developing the second generation of insects, which led to their mass reproduction. The bark beetles of the genus typographer affect mainly old spruce trees of 70-80 years [6]. Breeding outbreaks occur regularly and have been reported since the $19^{\text {th }}$ century [7]. The typographer beetle aside, the subfamily Scolytinae consists of 140 species that can be found in Europe, most of which feed on conifers.

The quality and viability of spruce stands depend not only on insects' mass reproduction but also moisture regime. The diameter of the spruce tree is directly related to the mass of needles [8]. According to various sources, about $20-30 \%$ of precipitation is retained in the crown and does not reach soil due to the dense crown [9]. A significant lack in soil moisture can be expected in sandy soils since water does not keep in the surface layer. The active growing season of spruce occurs from May to September; therefore, the amount of precipitation at this time is critical. According to studies, a lack of moisture should be expected in spruce trees older than 35 years, due to the difference between the moisture consumption for transpiration and the amount of moisture coming from the soil [10].

Recently, a progressive drying of spruce forests and stands occurred in Europe [11]. (DeMarco et al. 2017). This is primarily due to global warming, particularly, a decrease in precipitation. The decrease in precipitation causes more outbreaks of insects, affecting more and more areas of spruce forests and stands. Therefore, the method for monitoring spruce stands using modern technologies should be introduced, namely, the development of interactive spruce stands maps using geographic information system (GIS technologies) and unmanned aerial vehicles (UAVs) [12-15].
Generally, the UAVs have been previously used for exploration, monitoring of oil and gas pipelines, and identifying foci of forest fires. The cost of UAVs production was significantly reduced due to technical progress, thus it possible to use them in monitoring the ecosystems, including forest. The UAVs are commonly used in the EU countries, the USA, Japan and China to search forests for lost people, track the extent of forest fires, and detect large gatherings of insect pests. In China, drones are used in agriculture for irrigation purposes

The study attempts to develop interactive spruce stands map of the Moscow region using data obtained with UAVs and GIS technologies. The method helps to carry out a full-fledged, express assessment of spruce stands, covering large areas. Moreover, the data from different years allows us to assess the dynamics of the succession or degradation processes occurring in spruce stands over the decades. Despite the great forest cover of the territory (from 40 to $50 \%$ on average), the Moscow region is a convenient model territory due to intensive development and the felling of spruce stands. The data obtained can be used to study the influence of the territory expend to a megalopolis (Moscow) on forest ecosystems and their structure, on the example of spruce stands.

The aim of the study is to develop interactive spruce stands map of two model landscapes of the Moscow region, considering the foci of insects' mass reproduction. The tasks of the research included: a) development of interactive spruce stands map and related tree species using GIS technologies; b) study the dynamics of succession and degradation changes in spruce stands of the Moscow region (Russia) during 1991-2016; c) development of a model map of the anthropogenic landscape with a predominance of spruce stands using UAV data.

\section{Experimental Procedure}

\section{Study Location}

The Klinsko-Dmitrovskaya Gryada has an elevation of 290-310 m above sea level. Gryada is made up of Cretaceous rocks, which are overlapped by rocks of the Quaternary age. Since, gryada was several times affected by repeated glaciations (the last occurred about 170-125 thousand years ago) its landscape characteristics are associated with moraines, determining the structural and mechanical composition of soils. The Istrinsky landscape is located in the lowlands of the gryada, at altitudes up to $170 \mathrm{~m}$ above sea level. The Istrinsky district is made up of outcrops of Jurassic clays, thus, there is high humidity. The moraine was eroded by the melting of the glacier. This landscape is characterized by intensive development, gardening, development of rural power, and deforestation. 
The main part of the Meshchera Lowlands is located on the territory of the Vladimir and Ryazan oblast. The lowland has an elevation of 80 to $130 \mathrm{~m}$ above sea level. The lowland was developed due to glacier glow. Further, the Jurassic clays were covered with sand and gravel. Thus, lakes and swamps were formed. The Luzgarinsky landscape is at the highest point of the lowland, on the bedrock ledges. The anthropogenic changes in the landscape are weakly expressed, thus, it's mostly natural.

\section{Study Design}

Studies using GIS technologies were carried out in 2016. The cartographic data in previous years started in 1991. The moraine and moraine-glacial landscapes of the Moscow region were selected for processing GIS data in the study region. The landscapes were developed in the Quaternary period. Two geographical objects (Meshchera Lowlands and Klinsko-Dmitrovskaya Gryada) were selected, within which are two model landscapes - Istrinsky and Luzgarinsky, respectively.

For UAV analysis, the territories adjacent to the urban-type settlement Kurilovo were selected. Kurilovo is located $13 \mathrm{~km}$ from Podolsk city, Moscow oblast. The site includes 190 hectares, 123.6 hectares of which are forests. The rest of the territory is occupied by urban development and infrastructure facilities. The forests growing on this territory belonged to the sub taiga, broad-leaved-spruce forests that were subsequently cut down. Currently, the territory is mainly occupied by spruce stands aged 45-50 years old. The studies were carried out in 2019, during July-August.

\section{GIS Research Methods}

These studies were carried out in four stages. At the first stage, a cartographic data was collected, in particular, a forest inventory database. Map of forest formations in the Moscow region, scale 1: 200,000, was selected as a baseline. The map contains information collected from 1991. The map included data onforests' area and their composition (areas fell on stands, native trees, and conditional inference forests and derivatives). The classification was provided by G.I. Vorobyov [16]. According to the classification, forests developed due to felling or natural disasters (fires, a strong wind blows, etc.) are called derivative forests. Generally, after the felling of primary coniferous forests, smallleaved forests grow - birch, aspen, alder forests. Forests can return to their original state due to successional processes - at the period of the first generation of the forest-forming bedrock (short-term productivity forests), 2-3 generations (long-term productivity), or more (conditional inference forests).

Maps, a scale of 1: 25,000, were used to analyze the dynamics of changes in the composition and areas of forests during 2007-2008. Maps were developed based on the results of forest inventory and data from funds of the Lomonosov Moscow State University (Moscow, Russia).

The second stage of research included an analysis of forests' conditions. The ratio of areas occupied by conditional inference forests communities, which include native tree species - primarily spruce, along with pine (Pinus sylvestris L.) and English oak (Quercus robur $L$.) was assessed. Moreover, forest communities of small-leaved species, such as birch (Betulus pendula L.) and aspen (Populus tremula L.) were also considered. Meanwhile, these communities were considered due to the possibility of the main species renewal, including spruce.

The third stage included a comparison of maps and landscapes. A digital analogue of maps was also developed, snapping a point to a coordinate grid with the help of the ArcGis v. 10.2. The maps were compared with the satellite images taken in 2006 and 2008 (Landsat 5, Landsat 8). Images with $30 \mathrm{~m}$ spatial resolutions were used as the most optimal for maps with a scale of 1:200,000 and 1: 300,000. Moreover, preference was made for images from September, since at this time trees can be identified by their crowns. Thus, the images from 1991 to 2016 were compared to satellite images from 2006, 2008, 2014, and 2016. The fourth stage included an automated analysis of satellite images. For the unification of the analysis, the images were subjected to geometric and radiometric correction. Therefore, the brightness indicators of different areas in the images were converted into dimensionless brightness in the ERDAS Imagine. Each forest community was obtaining data on the average brightness of satellite imagery, namely, the blue, red, green survey, as well as the near-infrared survey. Further, the forest massif boundaries were obtained, using the k-means method and unsupervised classification, which were visually refined during the final processing. The resulting maps were exported to the ArcGIS software. The areas of forest communities were calculated in different years, based on the final mapping results.

\section{UAV Survey}

A lightweight UAV Ptero-E (AFM-Servers) was used as a model. The height was $300 \mathrm{~m}$. A Cannon Marck II camera was attached to the UAV. The matrix resolution is at least $4-5 \mathrm{~cm}$ (or $5616 \times 3744$ pixels). The images obtained were processed using the PhotoScan program, considering topographic maps. Thus, an ecological map was developed based on the ArcGIS program. The visual method was preferred, with an analysis of the size and shape of objects (forest areas, etc.), their location relative to human buildings, and also the position of objects relative to each other. The edaphic characteristics of the model territory were also considered, based on the corresponding maps developed by the Soil Science Institute of the Russian Academy of Sciences. 
a)

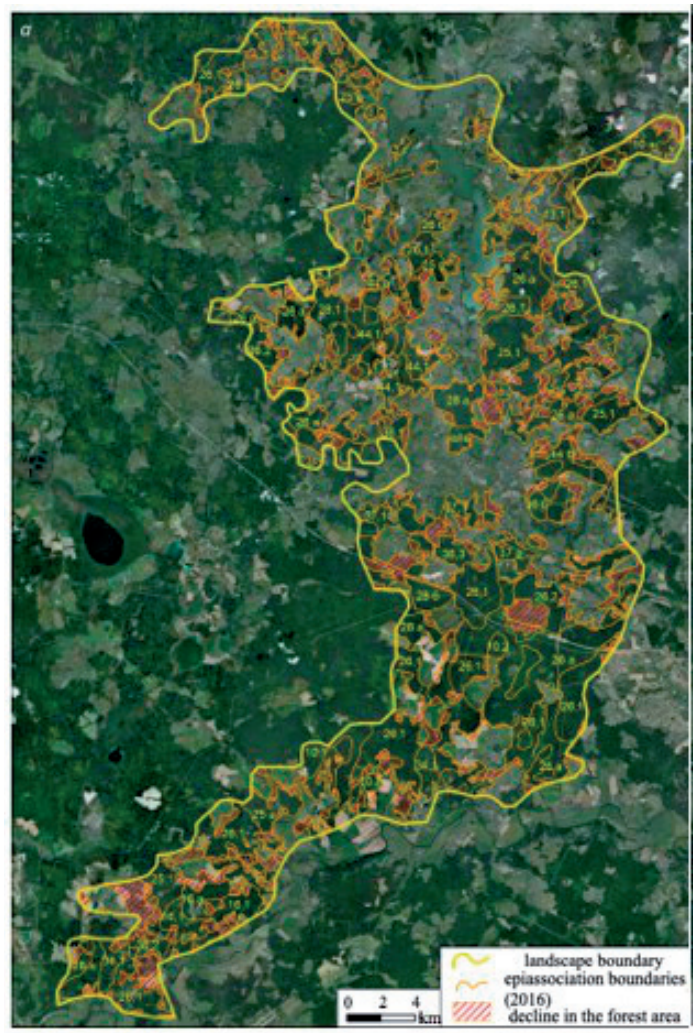

b)

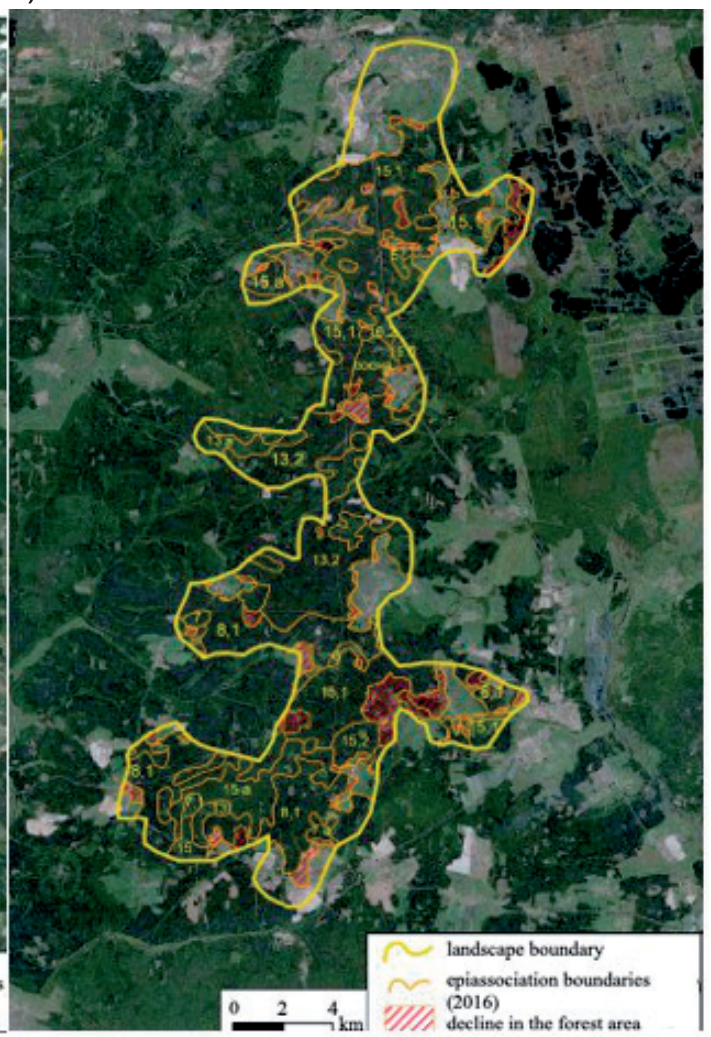

Fig. 1. Dynamics of areas reduction occupied by forests in 1991-2016 in the Istrinsky a) and Luzganinsky landscapes b).

\section{Results}

\section{GIS Mapping}

A predominance of spruce and pine-spruce forests is observed in the Istrinsky landscape (Fig. 1a), which make up background plant communities. Spruce and pine-spruce forests draw up to $55 \%$ of all forests in the landscape. Particularly, spruce forests make up about $40 \%$ while spruce-pine forests about $15 \%$.

Forests grow on depressions, mainly on the flat areas of moraine and water-glacial areas. They grow at altitudes of 180-220 m above sea level. Meanwhile, short-term productivity forests $(61 \%)$ and conditional inference forests $(5 \%)$ prevail among the plant communities in this area.

The high-resolution images helped to identify foci of spruce affected by bark beetles of the genus typographer. The lesions are located in the northern part of the ridge and occur on monodominant trees aged 100 years. Therefore, local forestry carried out clearfelling, which negatively affected the sustainability of forest communities. An analysis of the maps showed an increase in the fragmentation of forests and spruce stands.

The areas covered by a prime denote the forest area that has decreased from 1991 to 2016. The main figure is taken from satellite imagery data in natural colors. The figures indicate the types of plant communities: figure - conditional inference forests; fractional - shortterm productivity, with the dominance of spruce and pine; a figure with the letter - long-term productivity with the dominance of small-leaved species.

Coniferous (spruce) forests prevail in the Luzgarinsky landscape (Fig. 1b), making up $87 \%$ of the total forest area. The share of the Luzgarinsky landscape is about $70 \%$. The average age of spruce trees is $90-100$ years. The conditional inference forests $(15 \%)$ and short-term productivity forests $(70 \%)$ prevail. Fragmentation is not expressed, since forests are located densely. Forests grow in swampy lowlands, having the full the water balance in ecosystems.

The analysis of maps from 1991 to 2016 showed significant differences in a forest area in the Istrinsky landscape and insignificant in Luzgarinsky (Table 1).

According to Table 1, the forest area in the Istrinsky landscape has decreased by one- fifth, while changes in the Luzgarinsky are insignificant. Thus, the decrease in forest area has occurred in both landscapes.

Table 1. Change in forest cover in the Istrinsky and Luzgarinsky landscapes during 1991-2016 (in \%).

\begin{tabular}{|c|c|c|}
\hline Landscapes & 1991 year & 2016 year \\
\hline Istrinsky & 53.1 & 44.3 \\
\hline Luzgarinsky & 74.5 & 70.1 \\
\hline
\end{tabular}


The large changes in forest areas are quite expected in the Istrinsky landscape, located closer to the city of Moscow.

The analysis of the maps showed that changes in the structure of forests in both landscapes are not the same. Thus, in the Istrinsky landscape, the total areas of long-term productivity forests are 2 times less than that of short-term and conditional inference forests. Nevertheless, short-term productivity and conditional inference forests have decreased in area by $67 \%$, while long-term productivity - by $28 \%$. The total area of deforestation in this landscape was $53.5 \mathrm{~km}^{2}$ between 1991 and 2016.

The total area in the Luzgarinsky landscape also decreased due to $\mathrm{s}$ short-term productivity and conditional inference forests. Thus, these forests constitute the main area, so the overall picture has not changed.

\section{UAV Mapping}

The mapping data showed that the spruce forests are significantly affected by the bark beetles of the genus typographer. The area of insects' mass reproduction was 3.2 hectares. That is due to the age of the trees and

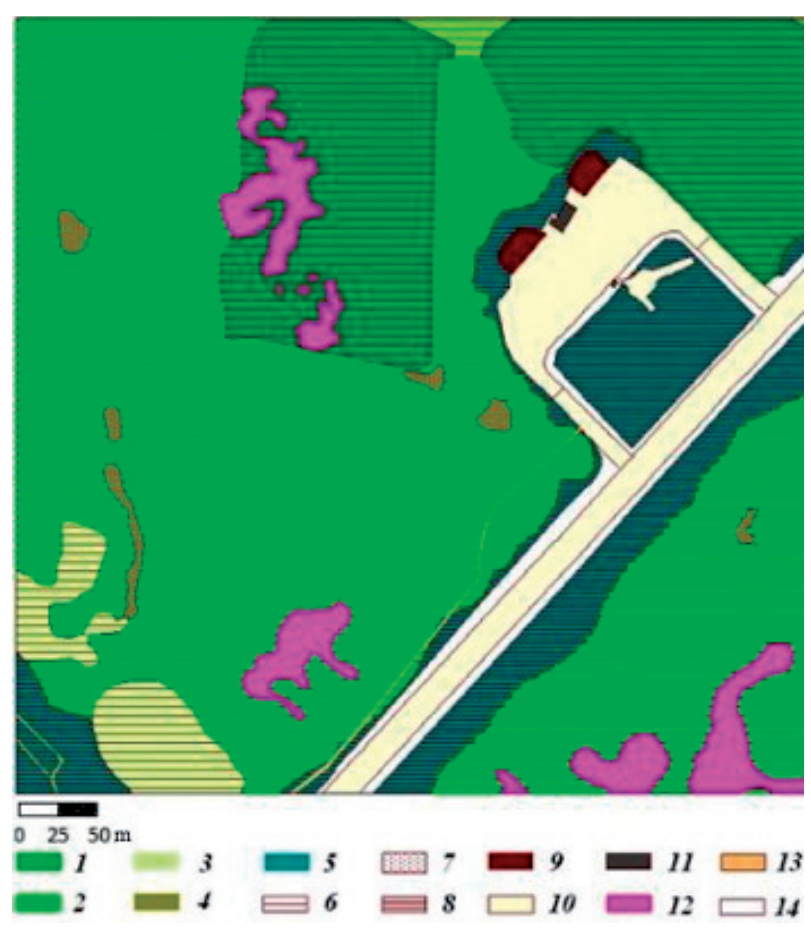

Fig. 2. Comprehensive ecological map of spruce stands in Kurilovo, map fragment. Scale 1: 2500.

Note: Prevailing types of plant communities (1-5). 1 - spruce stands up to 20 years old; 2 - up to 50 years old; 3 - birch-spruce forests; 4 - low-lying swamps; 5 - ruderal vegetation; 6 - sodpodzolic soils; 7 - gley soil; 8 - complex (sod-podzolic and urban soils); 9 - intrusems; 10 - ecranozems impermeable to water; 11 - ecranozems, under buildings; Ecological state; 12 - breeding of the bark beetles of the genus typographer in spruce stands; 13 - paths; 14 - roads. the nature of the stands (all single-species). Moreover, an insignificant recreational load in forests was observed. The total area of paths and roads does not exceed 0.5 hectares. Thus, anthropogenic is not the main negative factor determining the degradation of forest ecosystems.

Other types of landscapes are insignificant in the area (Fig. 2).

Spruce forests make up 93.6 hectares of the total forest area, the rest of the territory falls on swamps (10 hectares), quarries (5 hectares), ruderal vegetation (7 hectares), spruce stands up to 20 years old (8 hectares).

Thus, the dominant type of plant ecosystems will determine the direction of the processes occurring both in local territories and in larger areas. This has shown on the example of spruce stands, monospecific in composition, and over 50 years old, affected by bark beetles of the genus typographer. The UAV provides detailed mapping of small areas, which can serve as a model of the ongoing degradation and succession processes.

\section{Discussion}

The study shows that forest cover is one of the most important aspects that determine the resistance of forest ecosystems to the anthropogenic factor. According to some reports, forest cover below $45 \%$ reduces the conservation value of forests $[17,18]$. Species and age of trees are another important factors that determines the value of forests [19-21]. The spruce forests examined by GIS in the Meshchera lowland (Luzgarinsky landscape) consist mainly of trees within 100 years old. The accompanying species are pine and oak. Meanwhile, forests of this age are the most vulnerable to 1) mass reproduction of bark beetles of the genus typographer, and 2) selective deforestation by humans. Selective felling of primary forests can be not only due to the extraction of raw materials but also to localize the centers of mass reproduction of bark beetles of the genus typographer [22].

Nevertheless, the data from 1991 to 2016 showed that there is a widespread decrease in forest cover in the Moscow region. The maps help to carry out highquality monitoring of the forests over many years and to predict the tendency of changes for structural indicators (composition, age, area, forest cover, foci of mass reproduction of pests). These results apply not only to spruce forests but also to forest communities of other tree species.

The resistance of spruce forests to drying is directly related to moisture content, as well as soil fertility [23, 24]. The drying of spruces most often occurs on certain types of soils, in particular, sod-podzolic and podzolic. The drying up of spruce stands is not only associated with bark beetles of the genus typographer, but also with the properties of the soil cover. Recently, cases 
of spruce forests and stands drying have become more frequent in many European countries [3, 25]. No cases of mass drying of spruce were observed, except forest areas affected by bark beetles of the genus typographer. The drying is generally associated with recent abnormal summer temperatures. With the mass death of trees, there is a loss of food supply for many invertebrates [26], namely, aphids and ants [27]. Considering the role of these insects, a decrease in their number contributes to further degradation of forest ecosystems. Moreover, according to some data, single-species tree stands also contain depleted insect communities, in particular, ants, in comparison with forests [28]. With the mass death of single-species trees, there is no alternative source of food for insects. Thus, their population decreases. On the one hand, red wood ants are useless against the typographer beetle, and cannot fully extinguish outbreaks of its mass reproduction. There are cases when dry or dying trees became their nesting place, in conditions of strong shading, as was shown on the example of Formica rufa [29].

The lack of reproduction of the next generations is another reason for the instability of single-species manmade spruce stands. The undergrowth in monospecific tree associations is not viable, since it is not adapted for growing under the canopy of mature spruce trees [7, 30, 31]. The Luzgarinsky landscape has a high forest cover and low susceptibility to bark beetles, since includes not only spruce but other tree species - oak, pine, aspen, birch.

The reasons for deforestation of short-term and conditional inference forests in the Moscow Region may be different. Along with deforestation, sanitary felling is also possible, e.g. to prevent outbreaks of bark beetles of the genus typographer, which mainly cover old spruce trees.

The data obtained with UAV allows establishing some additional parameters: a) the number of trees in the upper layer; b) type of forest (natural, artificial); c) determination of the state of the spruce forest (how much it is affected by bark beetles of the genus typographer, how many dry-topped trees per unit area, how many trees of different species suffered as a result of strong wind blows and snow breakers); d) age and species of trees in the upper layers of the forest, as well as their seedlings and young growth in felling. The high resolution of images (up to $10 \mathrm{~cm}$ ) allows clarifying the necessary aspects of the study in detail. The listed data are not given in this article, except for paragraph $\mathrm{B}$ aimed at subsequent developments. The conducted research period did not allow processing all the information obtained by the UAV. The disadvantages of UAV are errors in determining the coordinates of the canter of the image, up to $10-15 \mathrm{~m}$, compering to GIS maps. This is due to the side drift of the UAV, as well as the rolls when vehicle maneuvers. The large number of images obtained is another disadvantage, which troubles information processing or takes more time. Moreover, the use of UAVs is useful in small areas. However, permission for shooting in private property is a separate obstacle.

\section{Conclusions}

The processing of satellite images showed an unequal decrease in forest cover for the spruce forests and stands during 1991-2016, namely from 53\% to $44 \%$ and from $73 \%$ to $70 \%$ in the Istrinsky and Luzgarinsky landscape, respectively. The reason is that the Istrinsky landscape is close to the metropolis (Moscow) unlike Luzgarinsky one. The total area of long-term productivity forests is twice less compering to shortterm productivity and conditional inference forests in the Istrinsky landscape. The short-term productivity and conditional inference forests decreased in area by 67\% during 1991-2016, while long-term productivity only by $28 \%$. The area of deforestation in the Istrinsky district was $53.5 \mathrm{~km}^{2}$.

The data obtained with the UAV helped to determine the area affected by the bark beetle: 3.2 out of 93.6 hectares of the total area of spruce forests. A detailed map of the surveyed area was obtained. The UAV helps to develop maps of drying trees, forest areas damaged by the strong wind blows, snow breakers, as well as dividing the study area into quarters with a different composition of tree species. These forests are at least 50 years old. UAV allows studying the state of tree undergrowth in felling areas. Forests affected by bark beetle are at least 50 years old. The use of UAVs is justified for monitoring small areas, up to 200 hectares, since the processing of images takes lots of time. Meanwhile, the accuracy of the images is at least $10 \mathrm{~cm}$ per 1 pixel, which exceeds the capabilities of free satellite imagery. The disadvantage of UAV is inadequate orientation in the images since there is always an error caused by the maneuvers.

\section{Aknowledgements}

The study was prepared based on research within the framework of the state-ordered research theme of the Institute of Geography RAS, no. 0148-2019-0008 (AAAA-A19-119022190170-1) 'Problems and prospects of Russia's territorial development in terms of its unevenness and global instability'.

\section{Conflict of Interest}

The authors declare no conflict of interest.

\section{References}

1. WALSHE D., MCINERNEY D., VAN DE KERCHOVE R., GOYENS C., BALAJI P., BYRNE K.A. Detecting 
nutrient deficiency in spruce forests using multispectral satellite imagery. Int. J. Appl. Earth. Obs. Geoinf. 86, 101975, 2020.

2. TUDORAN G.M., ZOTTA M. Adapting the planning and management of Norway spruce forests in mountain areas of Romania to environmental conditions including climate change. Sci. Total Environ. 698, 133761, 2020.

3. MAURER S., HEINIMANN H.R. Framework for assessing the windthrow risk to Norway spruce forests in Switzerland. Eur. J. For. Res. 139, 259, 2020.

4. ABDULLAH H., DARVISHZADEH R., SKIDMORE A. K., GROEN T.A., HEURICH M. European spruce bark beetle (Ips typographus, L.) green attack affects foliar reflectance and biochemical properties. Int. J. Appl. Earth Obs. Geoinf. 64, 199, 2018.

5. ABDULLAH H., SKIDMORE A. K., DARVISHZADEH R., HEURICH M. Sentinel-2 accurately maps green-attack stage of European spruce bark beetle (Ips typographus, L.) compared with Landsat-8. Remote Sens. Ecol. Conserv. 5 (1), 87, 2018.

6. NIKITINA A.D., KNYAZEVA S.V., GAVRILYUK E.A., TIKHONOVA E.V., EYDLINA S.P., KOROLEVA N.V. Vegetation cover dynamics mapping of the curonian spit national park using ALOS and SENTINEL-2 satellite imagery. For. Sci. Issues 3 (1), 1, 2020.

7. ANDREIEVA O., ZHYTOVA O., MARTYNCHUK I. Health condition and colonization of stem insects in Scots pine after ground fire in Central Polissya. Folia For. Pol. Ser. A For. 60 (3), 143, 2018.

8. DARVISHZADEH R., SKIDMORE A., ABDULLAH H., CHERENET E., ALI A., WANG T., NIEUWENHUIS W., HEURICH M., VRIELING A., CONNOR B. O., PAGANINI M. Mapping leaf chlorophyll content from Sentinel-2 and RapidEye data in spruce stands using the invertible forest reflectance model. Int. J. Appl. Earth Obs. Geoinf. 79, 58, 2019.

9. BELGIU M., DRAGU L. Random forest in remote sensing: a review of applications and future directions. ISPRS J. Photogramm. Remote Sens. 114, 24, 2016.

10. DASH J.P., WATT M.S., PEARSE G.D., HEAPHY M., DUNGEY H.S. Assessing very high resolution UAV imagery for monitoring forest health during a simulated disease outbreak. J. Photogramm. Remote Sens. 131, 1, 2017.

11. DEMARCO A., VITALE M., POPA I., ANAV A., BADEA O., SILAGHI D., LECA S., SCREPANTI A., PAOLETTI E. Ozone exposure affects tree defoliation in a continental climate. Sci. Total Environ. 596-597, 396, 2017.

12. FOREST EUROPE. Seventh Ministerial Conference on the Protection of Forest in Europe. Technical Report; Forest Europe: Madrid, 2015.

13. FASSNACHT F.E., LATIFI H., STEREŃCZAK K., MODZELEWSKA A., LEFSKY M., WASER L.T., STRAUB C., GHOSH A. Review of studies on tree species classification from remotely sensed data. Remote Sens. Environ. 186, 64, 2016.

14. GORELICK N., HANCHER M., DIXON M., ILYUSHCHENKO S., THAU D., MOORE R. Google Earth Engine: planetary-scale geospatial analysis for everyone. Remote Sens. Environ. 202, 18, 2017.

15. KEMPENEERS P., MCINERNEY D., SEDANO F., GALLEGO J., STROBL P., KAY S., KORHONEN K. T., SAN-MIGUEL-AYANZ J. Accuracy assessment of a remote sensing-based, pan-European forest cover map using multi-country national forest inventory data. IEEE J. Sel. Top. Appl. Earth. Observ. Rem. Sens. 6 (1), 54, 2013.
16. VOROBYOV G.I. Forest Encyclopedia. Soviet Encyclopedia Publishing House: Moscow, 1985.

17. SCHELHAAS M.J., NABUURS G.J., HENGEVELD G., REYER C.H., HANEWINKEL M., ZIMMERMANN N., CULLMANN D. Alternative forest management strategies to account for climate change-induced productivity and species suitability changes in Europe. Reg. Environ. Change 15, 1581, 2015.

18. MCINERNEY D., KEMPENEERS P., MARRON M., MCROBERTS R.E. Analysis of broad leaf encroachment in coniferous forest plantations using multi-temporal satellite imagery. Int. J. Appl. Earth Obs. Geoinf. 78, 130, 2019.

19. SHARMA R.P., BRUNNER A. Modeling individual tree height growth of Norway spruce and Scots pine from national forest inventory data in Norway. Scand. J. For. Res. 32 (6), 1, 2016.

20. WEISKITTEL A.R., HANN D.W., KERSHAW J.A. JR., VANCLAY J.K. Forest Growth and Yield Modeling; Wiley-Blackwell: Oxford, 2011.

21. HEINRICHS S., AMMER C., MUND M., BOCH S., BUDDE S., FISCHER M., MÜLLER J., SCHÖNING I., SCHULZE E. D., SCHMIDT W., WECKESSER M., SCHALL P. Landscape-scale mixtures of tree species are more effective than stand-scale mixtures for biodiversity of vascular plants, bryophytes and lichens. Forests 10 (1), 73, 2019.

22. SECELEANU I. Amenajarea pădurilor - organizare și conducere structural; Editura Ceres: Bucharest, 2012.

23. HARTLEY M.J. Rationale and methods for conserving biodiversity in plantation forests. For. Ecol. Manag. 155 (1-3), 81, 2002.

24. BOCH S., PRATI D., MÜLLER J., SOCHER S., BAUMBACH H., BUSCOT F., GOCKEL S., HEMP A., HESSENMÖLLER D., KALKO E. K. V., LINSENMAIRI K. E., PFEIFFER S., POMMER, U., SCHÖNING I., SCHULZE E.-G., SEILWINDER C., WEISSER W. W., WELLS K., FISCHER M. High plant species richness indicates management-related disturbances rather than the conservation status of forests. Basic Appl. Ecol. 14 (6), 496, 2013.

25. ARKHIPOVA M.V. Variation in forest area on the Central Russian Upland within the last 250 years. Contemp. Probl. Ecol. 8, 830, 2015.

26. JAROLÍMEK J., MASNER J., ULMAN M., DVOŘÁK S. Cloven-hoofed animals spatial activity evaluation methods in Doupov Mountains in the Czech Republic. Agris. Online Papers Econ. Inf. 4, 41, 2012.

27. STUKALYUK S.V. A case of vertical seasonal polydomy in Formica rufa (Hymenoptera; Formicidae). Russ. J. Ecol. 48, 583, 2017.

28. IHNATIUK O.A., STUKALYUK S.V. Degradation changes in the structure of multispecies associations of ants in urbanized areas. Russ. J. Ecol. 46, 109, 2015.

29. STUKALYUK S.V. The effect of climatic factors on the activity of ants (Hymenoptera, Formicidae) in Broadleaf Forests of Kiev. Communication 2. Entmol. Rev. 97, 1234, 2017.

30. FANG Z., BAO W., YAN X., LIU X. Understory structure and vascular plant diversity in naturally regenerated deciduous forests and spruce plantations on similar clearcuts: implications for forest regeneration strategy selection. Forests 5, 715, 2014.

31. GÓRSKA M., ROSZYK E. Wood structure of Scots pine (Pinus sylvestris L.) growing on flotation tailings. Folia For. Pol. Ser. A For. 61 (2), 112, 2019. 